\title{
The impacts on tikanga of the Hindu practice of scattering human ashes into waterways compared with the practice of disposing of blood via the wastewater system as part of the arterial embalming process ${ }^{1}$
}

“...the human corpse can be conceptualized as a threat to public health, as a sacred object, as an object of considerable political or metaphysical power, as an aesthetic medium, as a source of nutrients, as a commodity, and as a form of material waste-call it "necro-waste"

(Olson, 2016, p. 327)

\section{Introduction}

On 24 December 2019, Newshub featured a story entitled Hindu leader urges councils to create dedicated areas for scattering ashes (Fyfe, 2019). The story claimed that a Hindu leader by the name of Rajan Zed issued a statement asking that councils in Auckland, Wellington, Christchurch, Hamilton, and Tauranga create dedicated areas along bodies of water where Hindus may scatter the ashes of their dead into flowing water (Fyfe, 2019). As the story spread on Facebook and elsewhere, it engendered

1 For his invaluable lived insights into Hinduism and Hindu death rituals, I have consulted with my partner, "Baba". 
some polarising responses. Fyfe (2019), rightly noted, that the practice goes against tikanga.

Tikanga are correct procedures, customs, habits, ideas, beliefs, lore, methods, manners, rules, ways, codes, meanings, plans, practices, conventions, and protocols developed over time and determined by Māoriwhānau, hapū, and iwi (Mead, 2016; Moorfield, 2011; Williams, 1971). A universal tikanga among Māori is the understanding that human remains are tapu. Tapu is a form of ritual restriction that can limit day-to-day activities. For example, if a person drowns in the sea, local Māori will place a rāhui or provisional ritual prohibition on the area because the tapu surrounding death contaminates people, land, and water (Mead, 2016; Moorfield, 2011). The pollution of death is such that normal daily activities may not take place until Māori have determined otherwise.

As Māori consider human remains to be tapu, the central argument of this paper is that both the Hindu practice of scattering human ashes into waterways, and the disposal of human blood into the wastewater system-which is ultimately discharged into waterwaysas part of the vascular embalming process, breach tikanga. This paper will argue that both practices negatively impact on tikanga because of the ritual pollution associated with death.

This paper will summarise Māori religion, tapu, and traditional Māori death practices. This paper will provide a basic outline of some general aspects of Hinduism and Hindu death rituals. This paper will discuss the impacts on tikanga of the Hindu practice of scattering human ashes into waterways and compare this with the disposal of blood into the sewerage system as part of the arterial embalming process-a practice that many, if not, most, Māori engage in wittingly or otherwise. While the two practices are different-the former being directly connected to Hindu theology concerning samsara (the cycle of life and rebirth), karma (spiritual cause and effect), and moksha (liberation of the soul from the cycle 
of rebirth), and the latter being a result of a mortuary sanitation procedure used to preserve the body-both practices impact negatively on tikanga. This paper will also discuss some potential remedies for both issues.

\section{Māori religion and tapu}

Māori religion begins with the creation by Atuacommonly referred to, somewhat inaccurately, as the gods - that reside and are active in the physical world (Moorfield, 2011). Atua are more accurately described as ancestor deities with continuing influence over particular domains; for example, Tangaroa, Atua of the sea, and Tāne, Atua of the forest (Moorfield, 2011). There are many different Māori creation narratives. In some traditions, the creation process-which ultimately starts with Te Kore-is initiated by Io, the Supreme Creator.

Emanating from the cosmic incubator of Te Kore emerged Te $\mathrm{Po}$; and out of the numerous developmental stages of $\mathrm{Te} \mathrm{Po}$ came the primordial parents, Papatūānuku and Ranginui, who, while incessantly clasped to one another, produced a number of progeny (Marsden, 2003; Mikaere, 2011; Reilly, 2018). The offspring of these ancient parents grew dissatisfied with the darkness that resulted from their parent's unending embrace, and so one of the children, Tāne, pushed Ranginui and Papatūānuku apart, which moved the universe into a new stage, Te Ao Mārama-the world of life and light (Mikaere, 2011; Moorfield, 2011; Reilly, 2018). Within Te Ao Mārama, human life was created through the materialisation of the human form, and through sexual intercourse; Tāne formed the first woman, Hine, and procreated with her (Mikaere, 2011; Moorfield, 2011; Reilly, 2018). Tāne later married his first-born daughter, Hinetitama, who fled to Rarohenga, the Underworld, after discovering that her husband was also her father (Reilly, 2018). She became Hinenuitepō, Atua of the Underworld, where she awaits the dead (Reilly, 2018). 
In the Māori religion, priests were known as tohunga-these were priestly experts who mediated between Atua and the tribe (Keane, 2011; Marsden, 2003; Moorfield, 2011). Ritually restricted by tapu, a tohunga's role was to maintain tikanga; guide and lead the tribe concerning spiritual affairs; protect the tribe from malevolent spiritual influences; heal physical and spiritual illnesses; guide appropriate rituals for horticulture, fishing, bird hunting, and war; lift the tapu from new houses or waka; and place and lift tapu in death rituals (Best, 1976, 1982; Buck, 1950; Keane, 2011; Ngata, 2014; Tregear, 1904).

Māori religion contains several imperative spiritual concepts, including mana (inherited and/or earned prestige/power), tapu (ritual restriction) and noa (unrestricted), mauri (life force), and wairua (spirit).

Central to the argument in this paper is the notion of tapu. Tapu refers to restriction, prohibition or a supernatural condition; to be tapu, a person, place or thing was dedicated to an Atua and made sacred and untouchable (Marsden, 2003; Mead, 2016; Moorfield, 2011; Sissons, 2016). In Māori life and religion, certain places and objects were imbued with tapu. Wāhi tapu, or areas considered tapu, included burial grounds and areas where people had died (Best, 1976; Mead, 2016; Moorfield, 2011; Sissons, 2016). That human remains are considered tapu by Māori is of critical importance to tikanga.

\section{Traditional Māori death practices}

Māori embalmer, Rikki Solomon's (2016) exegesis entitled, He Whare Köiwi: Integrating traditional and contemporary funeral practice for the modern Māori, contains invaluable information gleaned from participants who gifted their Indigenous knowledge to his Master of Applied Indigenous Knowledge project and exegesis. Drawing on this information, Solomon (2016) explains that tūpāpaku were taken care of in ways that 
reflected the environment of the whānau, hapū, and iwi involved. In some areas, tūpāpaku were primarily disposed of through tree and cave burial. Here, the body was placed in a tree and exposed to the elements, insects, and birds as a means of natural excarnation. The bones were later interred in a cave. In other areas, tūpāpaku were simply buried in the sand. In some traditions, the sea was used in a process to purge the body which was then treated with kawakawa leaves. In some examples, tūpāpaku were placed into underwater caves. In other areas, tūpāpaku were placed on inaccessible cliffs.

The word tūpāpaku is used by Māori to mean a corpse. However, the word tūpāpaku, in a literal sense, means to stand shallowly (Williams, 1971). When a person in Māori society died, it was the obligation of close relatives to prepare the body for the funeral rites; the body-anointed with shark oil, and sometimes kōkōwaiwas bound into a sitting position with the knees up to the chin and the arms wrapped around the legs (Buck, 1949; Higgins, 2011; Oppenheim, 1973). Adorned according to rank, the body sat in a trussed position which Best (1934) argues was "a very far-spread custom - indeed, a worldwide one" (p.107). 


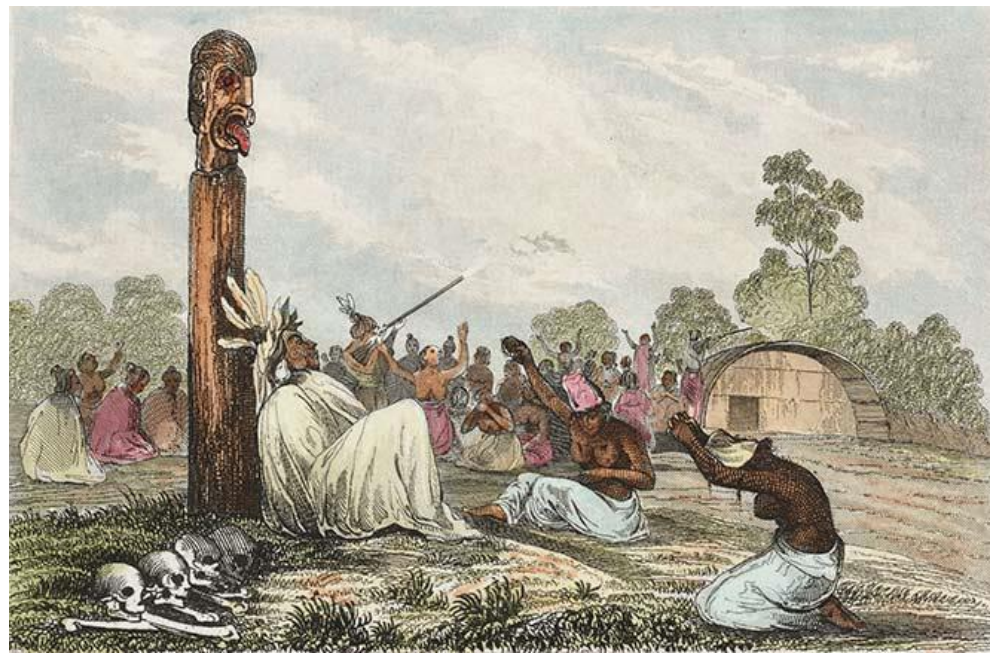

Figure 1. Mourning scene in New Zealand (Sainson, 1827-

1836). Though there are activities depicted in this image that are inaccurate, it correctly demonstrates how the tūpappaku was trussed and displayed for tangihanga (Higgins, 2011).

Reflecting on the tangihanga of my fourth greatgrandfather, Peraniko Tahawai, Ariki of Ngāti Manawa, Gilbert Mair (1923) wrote:

Lifting my eyes to the front of the carved house, imagine my feelings on being confronted with my deceased friend Peraniko, who had been exhumed from the grave wherein he had lain for two years. The body had been carefully washed; his jet-black hair, which had grown very long, was oiled and ornamented with rare plumes of the huia and white crane. He was seated on a high structure plentifully adorned with choice mats, while his cold hand still grasped the family talisman, a greenstone mere. 
Death had wrought no change, nor was there the slightest odour (pp. 65-66). ${ }^{2}$

Following a tangihanga, the flesh from the corpse was left to rot away using various means such as suspension in a tree, burial in the earth or sand dune, placement in a designated body of water, or in whatever way deemed appropriate (Solomon, 2016). While some Māori did use certain designated bodies of waterdirected, of course, by tohunga-as part of a natural defleshing process, this practice was abandoned as a result of colonisation and Christianisation (Selket, 2010; Solomon, 2016). In some areas, sea caves were used for sea burials $(\mathrm{H}$. Maclean, personal communication, February 14, 2020). In other areas, streams were used for water burials (J. MacFie, personal communication, February 14, 2020). In both cases, the corpse was placed inside the sea cave or stream and left to disintegrate and the bones were later collected, cleaned, and prepared for the hahunga ritual (J. MacFie, personal communication, February 14, 2020; H. Maclean, personal communication, February 14, 2020). Best (1934) states:

In many cases the body was buried, and every few years a hahunga tupapaku, or exhumation of the dead, took place. On these occasions a number of dead were exhumed - that is to say, the bones were taken up, cleansed, and taken to the village. There they were placed upon an elevated platform, and a

2 According to Wharehuia Milroy (Personal communication, 5 September, 2013) in some areas like Murupara where there is an abundance of pumice in the soil, bodies were sometimes stored and preserved in the ground where the pumice acted as a means of preservation; when a body needed to be resurrected for tangihanga proceedings-which could last for weeks, months or years, depending on the rank of the deceased person-the body was removed from the earth and placed again on the marae. 
considerable amount of ceremonial speech-making and feasting was indulged in(p. 107).

Concerning the final disposal of the bones following the hahunga ceremony Best (1934) opines:

As to the final disposal of the bones of the dead, they were conveyed to some cave or chasm far from the haunts of man, or placed in a hollow tree. On several occasions I have come across such remains in hollow pukatea trees (p. 108).

Cremation was sometimes used by Māori but was by no means common (Best, 1914). According to Best (1914) Māori practiced cremation for the following reasons:

1. When a tribe occupied open country wherein were found no suitable places for the final disposal of the bones of the dead after exhumation.

2. When a raiding party (or even peaceful travellers in some cases) lost members by death outside their tribal boundaries. ${ }^{3}$

3. Occasionally practiced in order to stay the spread of disease (p. 110).

\section{Hinduism}

Hinduism is one of the oldest religions in the world (Dallapiccola, 2002; Parthasarathy, 2013; Samarth, 2018; Wangu, 2001). Hinduism was not founded by a particular individual but results from various religious beliefs, practices, and philosophies that evolved over 4,000 years (Dallapiccola, 2002; Parthasarathy, 2013; Samarth, 2018; Wangu, 2001). While Hindusim might be

${ }^{3}$ Best (1914) argues that in some cases, when a person was killed in battle or died for other reasons outside of one's tribal area, the body was burned and the head was cured and taken home to be mourned over. 
considered by some a polytheistic religion, some also believe that there is only one God, Brahman and that all gods are part of the one God (Dallapiccola, 2002; Parthasarathy. 2013; Wangu, 2001). Brahman is the non-gendered "All-pervading, self-existent power" and the "supreme entity of the universe, from which all things emanate and to which all return" (Dallapiccola, 2002, p. 42). Parthasarathy (2013) argues vehemently that Hindus certainly are not polytheistic and that the various and voluminous members of the Hindu pantheon are only signifiers of the presence of Brahman, the Supreme God, in the physical world.

A universal belief in Hinduism is that there are many different individual paths through which one may attain moksha - the release from the physical world and unity with God (Dallapiccola, 2002; Parthasarathy, 2013; Wangu, 2001). The following rituals, beliefs, and traditions are important to Hindusim: puja-daily worship; dharma-religious duties concerning family and society; samskara-rites of passage; samsarareincarnation; karma-actions and deeds determine future life of the soul; and moksha-the soul's final release from the material world (Dallapiccola, 2002; Parthasarathy, 2013; Samarth, 2018; Wangu, 2001). A Hindu worldview understands the material world to be "unreal", while the world of the mind and spirit is considered real (Dallapiccola, 2002; Parthasarathy, 2013; Wangu, 2001). Thus, if a person spends their life building on materiality, their karma may result in further rebirths; whereas, moksha can only be attained by a life spent in oneness with God (Dallapiccola, 2002; Parthasarathy, 2013; Wangu, 2001).

Hindu creation depictions are based around cycles of creation and destruction. There are numerous Hindu creation narratives but one of the more popular stories involves a cosmic golden egg or golden womb-initially associated with the "Cosmic Soul" and later with Brahma (the masculine personification of Brahman)-which hovered above the waters in the obscurity of nothingness 
(Dallapiccola, 2002). In due course, the egg split open and from there emerged heaven-from the golden upper half, earth-from the silver lower half, and 21 regions of the cosmos (Dallapiccola, 2002). From the inner membranes came the mountains, and from the outer, the clouds; from the veins and fluids developed the rivers and oceans (Dallapiccola, 2002). Several other deities-the identities of which vary according to tradition-joined Brahma in creating the universe (Dallapiccola, 2002).

In Hinduism, cremation is a theological necessity (Caixeiro, 2005; Dallapiccola, 2002; Oestigaard, 2005, 2013; Samarth, 2018). As all things come from God, all things must return to God (Dallapiccola, 2002). The human form is offered to the fire which excarnates the bones and diffuses the bodily elements-earth, fire, air, water, ether (Caixeiro, 2005; Dallapiccola, 2002; Oestigaard, 2005, 2013; Samarth, 2018). The remaining fragments are then immersed in a river-considered to be a feminine deity, a mother (Caixeiro, 2005; Dallapiccola, 2002; Oestigaard, 2005, 2013; Samarth, 2018). The act of preparing the body as a sacrifice to God and cremation is part of a process of purification of the soul (Oestigaard, 2005). Certainly for Hinduism, "death is a purifying process, not a polluting process" (Oestigaard, 2005, p. 166).

\section{Hindu death rituals}

Samarth (2018) opines: "Death is a critical moment in the life of a Hindu, not only because it marks the end of life, but also because it marks the transition to the afterlife and next life" (p. 15). Associated with death, Chattopadhyaya (1993) states that moksha is the liberation of the soul from the process of reincarnation. Prajapati and Bhaduri (2018) opine that when a person has achieved moksha they are free from samsara-the cycle of life and rebirth. Hindu cremation and its associated rituals are intended to free the soul to allow it to achieve moksha, or if this not possible, to at least 
achieve a higher form of existence in the next life (Prajapati \& Bhaduri, 2018).

Hinduism has one of the "longest and most complex traditions" of using cremation as a means of "treating the dead and relating them to an overarching theory of life and death" (Davies, 2005, p. 233). Within Hindusim, cremation-considered to be an "act of creation""entails engaging with the philosophical and mystical dimensions of death" (Caixeiro, 2005, p. 234). For Hindus, cremation is understood to be a type of firesacrifice of the self-a mode of transformation featuring a "ritual tearing of life out of death" where "both the world and the sacrificer are reborn" (Caixeiro, 2005, p. 234). Hindus believe in the rebirth and reincarnation of the soul, and as such:

death is not a great calamity, not an end of all, but a natural process in the existence of the soul as a separate entity; in death, the soul reassembles its sources, adjust its course and returns to the earth to continue its journey (Caixeiro, 2005, p. 234).

Death in Hinduism, therefore, "is a temporary cessation of physical activity, a necessary means of recycling resources and energy, and an opportunity for the jiva (the incarnating part) to review its programmes and policies" (Caixeiro, 2005, p. 234). A person, Caixeiro (2005) opines, "is never entirely new when born, and never entirely gone when dead" (p. 234).

Hindu funeral rites, Samarth (2018) argues, "are among the most elaborate rituals in Hindu tradition" (p. 16). ${ }^{4}$ While the mode of cremation varies according to status and wealth, ideally, when a Hindu person dies the corpse should be washed, anointed with ghee, perfumed, covered in flowers, and wrapped in a white cloth; pieces

\footnotetext{
${ }^{4}$ See Samarth's (2018) doctoral thesis, The survival of Hindu cremation myths and rituals in 21st century practice: Three contemporary case studies, for a comprehensive discussion concerning Hindu death rituals.
} 
of gold should be placed in the mouth and nostrils "as a means through which the body may be worshipped" (Caixeiro, 2005, p. 234; Samarth, 2018). Indeed, Samarth (2018) states that the rituals performed on the corpse are the same as those performed on Hindu deities and so the body is treated as a "deified-ancestor" (p. 24) and thus "elevated to the status of a deity" (p. 30).

The pyre becomes an altar and the body a sacrifice, while the act of cremation itself becomes an act of transformation through which the soul may be purified by fire and either transmigrate to a higher form of earthly existence or attain moksha (Caixeiro, 2005; Dallapiccola, 2002). According to Sharma (cited in Ballard, 2006):

The corporeal body comprises of the five elements (air, water, fire, earth and ether) which must be offered during cremation as a 'final oblation' to the divine fire Agni. Agni is entrusted with safely reuniting these elemental forces and invoked by Vedic recitals and ritual offerings into the funeral flame itself (p. i).

When the body is burned and the ashes are dispersed into a river, the cremation cycle is complete (Oestigaard, 2013).

In Aotearoa New Zealand cremation is carried out at a Crematorium. The corpse, wrapped in a shroud or a casket, is placed into a chamber and burned at a temperature of 800 to 1000 degrees Celsius (Auckland Council, 2019a). Following the cremation, all that is left in the chamber is calcified bone fragments which are processed into fine granules in a cremulator machine (Auckland Council, 2019a). These "ashes" are then placed into an appropriate receptacle and given back to the family (Solomon, 2016). 
A comparison of the Hindu practice of scattering human ashes into waterways with the practice of disposing of blood via the sewerage system as part of the arterial embalming process

With 500 million people living in the catchment of the Ganga, Polaki and Bekkam (2014) estimate that 15,000 tonnes of cremation ash along with a further 140 to 250 tonnes of partially burned corpses are disposed of in the river each year. This waste, along with other organic and inorganic pollutants have, Dwivedi et al. (2018) argues, caused acute deterioration to the water quality of the Ganga, posing a significant risk to public health, particularly, concerning the consumption of fish containing bioaccumulated toxicants. ${ }^{5}$ Similarly, cremation ash, disposed of into the Godavari River in the state of Maharashtra, as part of a mixture of other pollutants have, according to Bhalla et al. (2012), resulted in a "change in physic-chemical and biological characteristics" of the river water (p. 43). A further example concerns the water quality at the Nigambodh Ghat-a major cremation site on the River Yamunawhere 50 to 60 pyres are burned daily and cremation ashes and unburnt flesh is immersed in the waterway (Kaur \& Mehra, 2011). ${ }^{6}$ Kaur and Mehra (2011) opine that cremation ash adds phosphates to the water which is a major reason for the reduction of water quality at that site.

Cremated human remains are high in phosphates, calcium, potassium, and sodium, but in concentrations that are not balanced for plant life and which can scorch plants and cause browning (Roberts, 2017). Cremated human remains also contain high levels of sodium-200

\footnotetext{
5 See Narayanan's (2001) article, Water, wood, and wisdom: Ecological perspectives from the Hindu tradition, to read more about the tension between a Hindu worldview and real world practice and the effects of this on India's great rivers.

6 See Nanoo's (2016) thesis, The Existential Theatre presents the reincarnation of architecture or the reincarnation of cremation architecture, for further explanation of the Ghat and an architectural analysis of Hindu death rituals.
} 
to 2000 times higher than plant life can withstand (Roberts, 2017). Cremated remains, therefore, should be considered a source of physical contamination to waterways. According to the Auckland Council (2019b), cremated remains "can pollute our harbours and other open spaces, causing harm to plants, birds and fish" (n.p.).

According to Statistics New Zealand (2019) in 2018, 121,644 people in Aotearoa New Zealand identified as Hindu. While the number of Hindu people in Aotearoa New Zealand needing to scatter the ashes of their loved ones into waterways would be relatively low, the practice still violates tikanga. It should be noted too that other religious groups also prefer to dispose of human ashes by immersion in waterways, while other individuals may request that their ashes are disposed of in this way as a personal preference. As previously noted, however, human remains are considered by Māori to be tapu. When human remains are scattered into the water, tapu ritually pollutes the water, while the chemical composition of the ashes also physically pollutes the water.

The ritual restriction of tapu is central to Māori life and death. When a Māori person dies, more often than not, a tangihanga at the marae ensues (Rangiwai, 2018). In preparation for the tangihanga, contemporary Māori have become accustomed to taking their dead to a funeral home to be embalmed (Rangiwai, 2018). Embalming is a chemical process whereby the corpse is sanitised and preserved which allows the whanau to proceed with the tangihanga, while maintaining a "dignified image" of the deceased (Rangiwai, 2018).

Mayer (2012) states that the modern embalming process is the chemical treatment of the tissues of a dead human body as a means of preservation and sanitation. According to the American Board of Funeral Service Education, embalming is "...the process of chemically treating the dead human body to reduce the presence and growth of microorganisms, to retard organic 
decomposition, and to restore acceptable physical appearance" (cited in Mayer, 2012, p. 32).

When a person dies, enzymes-which come from body cells (autolytic enzymes) or bacteria (bacterial enzymes) - cause the decomposition of proteins, fats, and carbohydrates in the decedent (Mayer, 2012). Embalming chemicals deactivate body enzymes and destroy both pathogenic and non-pathogenic bacteria (Mayer, 2012). The sanitisation of the body occurs when proteins in the tissues react with embalming chemicals (Mayer, 2012).

Problematically for tikanga, during the embalming process, blood is displaced by embalming chemicals and disposed of via the wastewater system (Rangiwai, 2018). To remove the blood of a dead human body and to dispose of it in this manner is a breach of tikanga that has become normalised through the perceived need for embalming (Rangiwai, 2018). Although human blood and other bodily fluids released into sewerage systems by hospitals and funeral homes are diluted by significant volumes of water and broken down in a treatment process designed specifically to treat organic materials (State of Ohio Department of Health Environmental Protection Agency, 1993) - such as oxidation ponds (Towndrow et al., 2010) - tapu is a ritual contamination that is not negated by the mechanical, biological, and chemical filtration processes of wastewater treatment.

\section{Possible remedies}

The scattering of human remains into waterways breaches tikanga. For Hindus, scattering ashes in this way is part of Hindu theology and culture. Tikanga can change and is determined by local Māori of a given area. Concerning the scattering of ashes into waterways, Auckland Council (2019b) states that it is imperative to "[s]peak to tangata whenua (people of the land) before scattering ashes in the ocean or flowing water" (n.p.). Therefore, a person wishing to scatter human remains should find out who the local hapū/iwi of the area are 
and consult with them concerning whether or not scattering of human remains is appropriate in the area. Potentially, the services of a tohunga-a priestly expert who may place or lift tapu (Best, 1976, 1982; Buck, 1950; Keane, 2011; Ngata, 2014; Tregear, 1904)—may be necessary. Indeed, local hapū/iwi are best placed to provide advice on the tikanga of their particular area. If permission is not granted, the disposal of human remains into a waterway breaks tikanga and is therefore offensive to local Māori.

With regard to preventing the disposal of human blood down the drains, some Māori elect to ask the funeral home to place the blood into a vessel so that they can bury the blood along with the corpse. Māori embalmer, Rikki Solomon has been asked by whānau to place the blood of a tūpāpaku into a container which was then placed into the coffin (personal communication, February 7, 2020). I have also heard of separate occasions where the blood from a tūpāpaku has been reserved in a plastic container and 1) transported on ice with the tūpāpaku where it has remained on-site at a marae but away from the main tangihanga proceedings and then buried with the corpse; and 2) transported to the urupā before the burial of the tūpāpaku and buried (Rangiwai, 2018). Reserving the blood and burying it in the earth with or near the tūpāpaku seems to satisfy the demands of contemporary tikanga as the elements of the body are united in the vicinity of the urupā or public cemetery (Rangiwai, 2018). However, I suspect that the contemporary Māori notion of going to the grave whole is one that has been shaped by Christianity. While I do not imagine that collecting the blood of a tūpāpaku is, as yet, a widespread practice for Māori, it is reasonable to expect that with increased awareness more Māori may choose this as an option.

A further issue is the toxic nature of the chemicals used in the embalming process and the potential effects of these on the environment. In The impacts of contemporary embalming practices on tikanga 
Māori (Rangiwai, 2018) I discussed two documented cases where embalming was not used. In both cases, alternative techniques were employed to temporarily preserve the dead bodies for an extended period. In one case, the corpse showed signs of decay fairly quickly due to summer weather conditions. However, philosophically and religiously, the state of decay was accepted by family and friends as a way of detaching from the life of their loved one, and as a means of realising the natural state of a dead human body and its life-giving potential for other lifeforms and for the soil (both bodies were buried as naturally as possible at a shallow depth to allow insects and worms access). In the other case, the use of ice at night slowed-down the decomposition of the corpse for the entire length of the tangihanga. In both cases, whānau and close friends participated in the anointing of the corpses with essential oils and other natural treatments, which contributed to their collective healing. In my view, the techniques used in both cases are completely in harmony with tikanga.

As an alternative to burial and cremation, Rikki Solomon (2016) proposes that Māori could consider the process of resomation. Resomation is a means of disposing of a human body by reducing it to bone "through the water-based resolving process of alkaline hydrolysis" (Fulcher, 2011, p. 1). According to Fulcher (2011):

During the process, a human body is placed in a pressurized stainless steel chamber, where water and the alkali solution potassium hydroxide are added, and the temperature is raised to $177^{\circ} \mathrm{C}$ $\left(350^{\circ} \mathrm{F}\right)$. The water and alkali solution, heat, and pressure combine to cause a chemical reaction that reduces a body to bones. During the hydrolysis process, water molecules are forced between the chemical bonds holding together large tissue molecules, such as fats, DNA, and proteins, 
breaking tissue down to its original small molecular building blocks (p. 1).

The process of "decomposition, which results in bones and liquid, takes anywhere from 5 to 25 years during normal burial but is accelerated to about 2 to 3 hours" via the resomation process (Fulcher, 2011, p. 1). The process produces a liquid that can be drained into the wastewater system to go through a treatment process along with other wastewater (Fulcher, 2011). Of course, the disposal of this fluid into the wastewater system, like the disposal of blood via the embalming process, breaks tikanga. A solution to this might be for the fluid to be collected and given back to whānau to inter in their burial grounds in some culturally appropriate way determined by them. Following resomation, the bones that are left behind can be crushed into "ash" and given back to whānau (Solomon, 2016). Solomon (2016) argues:

Resomation is an old practice that has been modified using new technology. Instead of placing tūpāpaku as our tūpuna did, into a river, swamp or ocean. The tūpāpaku is placed into a machine that breaks down the flesh down using water and potassium hydroxide until only the kōiwi remain. This is reflective of the traditional practices that our tūpuna had. At the end of the process, we still have the kōiwi (Solomon, 2016, p. 34).

\section{Conclusion}

Since the arrival of Pākehā, Māori have had to compromise and adapt our cultural traditions. Traditional Māori funeral practices concerning hahunga were prohibited through health regulations (Selket, 2010). Selket (2010) argues that since the arrival of Pākehā, "tangihanga has been targeted for various reasons by health and sanitation laws" (p. 97). Indeed, traditional Māori funeral practices were viewed by Pākehā 
as dangerous to health (Selket, 2010). Concerning cremation in crematoria in contrast to pyre cremation, Sharma (cited in Ballard, 2006) argues that Hindu ritual is severely compromised as certain functions-such as offering oblations to Agni, the divine fire-cannot be performed. Instead, offerings are placed on the corpse before it enters the chamber (Sharma, cited in Ballard, 2006). Therefore, if some aspects of Hindu death ritual can be compromised and adapted to suit legal and other restraints, then it follows that other parts of the ritual, such as the requirement for the scattering of ash into waterways, may also be changed to suit a different cultural context. Bearing in mind the significant compromises that Māori have made, it is not unreasonable to ask other cultures and religions to consider tikanga. 


\section{References}

Auckland Council (2019a). How cremation works [Webpage]. https://www.aucklandcouncil.govt.nz/cemeteries/crem ation/Pages/how-cremation-works.aspx

Auckland Council (2019b). Scattering of ashes [Webpage]. https://www.aucklandcouncil.govt.nz/cemeteries/crem ation/Pages/scattering-of-ashes.aspx

Ballard, R. (2006). The logic of cremation: Appendum 1. http://crossasia-repository.ub.uniheidelberg.de/466/2/2_Cremation_Addenda.pdf

Best, E. (1914). Cremation amongst the Maori tribes of New Zealand. Man, 14, 110-112. https://www.jstor.org/stable/2787457?seq=1\#metadat a info tab_contents

Best, E. (1934). The Maori as he was: A brief account of Maori life as it was in pre-European days. Dominion Museum.

Best, E. (1976). Maori religion and mythology (Vol. 1). Government Printer.

Best, E. (1982). Maori religion and mythology (Vol. 2). Government Printer.

Bhalla, R., Waykar, B. B. \& Sekhon, B. (2012). Water quality assessment of Godavari River water at Nashik. Environment Conservation Journal, 13(3), 43-48. Retrieved from https://environcj.in/wpcontent/uploads/issues/2012/3/ECJ-43-48.pdf

Buck, P. (1949). The coming of the Maori. Whitcombe \& Tombs.

Buck, P. (1950). The coming of the Maori. Whitcombe \& Tombs.

Caixeiro, M. (2005). Antiesthi: Traditional Hindu cremation. In D. J. Davies \& L. H. Mates, Encyclopedia of Cremation (pp. 234-235). Ashgate.

Chattopadhyaya, D. (1993). What is living and what is dead in Indian philosophy. People's Publishing House.

Dallapiccola, A. L. (2002). Dictionary of Hindu lore and legend. Thames \& Hudson.

Davies, D. J. (2005). Hindusim. In D. J. Davies \& L. H. Mates, Encyclopedia of Cremation (p. 233). Ashgate. 
Dwivedi, S., Mishra, S. \& Tripathi, R. D. (2018). Ganga water pollution: A potential health threat to inhabitants of Ganga basin. Environment International, 117, 327-338.

Fulcher, J. (2011). Bio cremation returns bodies to the environment. Water Environment Federation Highlights, 48(9),

https://search.proquest.com/docview/926350826?acco untid $=44427$

Fyfe, J. (2019, December 24). Hindu leader urges councils to create dedicated areas for scattering of ashes. Newshub. https://www.newshub.co.nz/home/newzealand/2019/12/hindu-leader-urges-councils-tocreate-dedicated-areas-for-scattering-of-ashes.html

Higgins, R. (2011). Tangihanga - death customs - traditional preparations for tangihanga. Te Ara: The Encyclopedia of New Zealand. http://www.teara.govt.nz/en/artwork/28780/tupapaku

Kaur, S. \& Mehra, P. (2011). Status of water quality of River Yamuna at Nigambodh Ghat: A major cremation ground in Delhi, India. International Journal of Advances in Engineering Research, 2(1), 1-11. Retrieved from http://www.ijaer.com/images/short_pdf/Jul_2011_Sim erjit\%20Kaur.pdf

Keane, B. (2011). Traditional Māori religion-ngā karakia a te Māori. Te Ara-Encyclopedia of New Zealand. Retrieved from https://teara.govt.nz/en/traditional-maorireligion-nga-karakia-a-te-maori

Mair, G. (1923). Reminiscences and Maori stories. Brett Printing \& Publishing.

Marsden, M. (2003). The woven universe: Selected writings of Rev. Māori Marsden. Estate of Rev. Māori Marsden.

Mayer, R. G. (2012). Embalming: History, theory, and practice (5 th Edition). McGraw-Hill

Mead, H. M. (2016). Tikanga Māori: Living by Māori values. Huia.

Mikaere, A. (2011). Colonising myths-Māori realities: He rukuruku whakaaro. Huia. 
Moorfield, J. C. (2011). Te Aka-Māori-English, EnglishMãori dictionary. Pearson.

Nanoo, A. (2016). The Existential Theatre presents the reincarnation of architecture or the reincarnation of cremation architecture [Unpublished master's thesis]. University of Witwatersrand. Retrieved from http:/ / hdl.handle.net/10539/21475

Narayanan, V. (2001). Water, wood, and wisdom: Ecological perspectives from the Hindu traditions. Daedalus, 130(4), 179-206. https://www.jstor.org/stable/20027723

Ngata, R. S. (2014). Understanding Matakite: A kaupapa Māori study on the impact of Matakite/intuitive experiences on wellbeing [Unpublished doctoral thesis]. Massey University. Massey University Research Repository. http://hdl.handle.net/10179/8299

Oestigaard, T. (2005). Cremation and cosmogony: Karma and soteriology. Dhaulagiri Journal of Sociology and Anthropology, 1 , 164-175. https://doi.org/10.3126/dsaj.v1i0.287

Oestigaard, T. (2013). Cremations in culture and cosmology. In S. Tarlow \& L. N. Stutz (Eds.), The Oxford handbook of the archaeology of death and burial (pp. 497-509). Oxford University Press.

Olson, P. R. (2016). Knowing 'Necro Waste.' Social Epistemology, 30(3), 326345. https://doi.org/10.1080/02691728.2015.1015063

Oppenheim, R. S. (1973). Maori death customs. A. H. \& A. W. Reed.

Parthasarathy, A. (2013). A symbolism of Hindu gods and rituals. A. Parthasarathy.

Polaki, L. \& Bekkam, V. R. (2014, December 15-19). Cultural dimension of water pollution [Conference session]. American Geophysical Union Fall Meeting.

Prajapati, V. N. \& Bhaduri, S. (2018). Human values in disposing the dead: An inquiry into cremation technology. Journal of Human Values, 25(1), 52-65. https://doi.org/10.1177/0971685818806416

Rangiwai, B. W. (2018). The impacts of contemporary embalming practices on tikanga Māori. Te Kaharoa: The 
eJournal on Indigenous Pacific Issues, 11(1), 229-249. Retrieved from: https://www.tekaharoa.com/index.php/tekaharoa/arti cle/view/213

Reilly, M. (2018). Te tīmatanga mai o te ao: The beginning of the world. In M. Reilly, S. Duncan, G. Leoni, L. Paterson, L. Carter, M. Rātima \& P. Rewi (Eds.), Te Kōparapara: An introduction to the Mãori world (pp. 12-39). Auckland University Press.

Roberts, W. (2017). A process for producing biocompatible soil mixture from cremated ash remains and ground penetrating apparatus thereof (PCT/AU2016/051 153). https:// patentimages.storage.googleapis.com/13/ed/47 Leca9f2ab38fdf9/WO2017088024A1.pdf

Sainson, L. A. (1827-1836). Mourning scene in New Zealand [Engraving]. (A-307-004). Alexander Turnbull Library, New Zealand. https://natlib.govt.nz/records/22833724

Samarth, A. G. (2018). The survival of Hindu cremation myths and rituals in $21^{\text {st }}$ century practice: Three contemporary case studies [Unpublished doctoral thesis]. University of Texas. University of Texas Research Repository https://utd-ir.tdl.org/handle/10735.1/5908 Selket, K. (2010). Exiled bodies and funeral homes in Aotearoa New Zealand [Unpublished doctoral thesis]. Victoria University of Wellington. https://core.ac.uk/download/pdf/41336576.pdf

Sissons, J. (2016). Dangerous remains: Towards a history of tapu. Sites, 13(2), 49-65. http://dx.doi.org/10.11157/ sites-vol13ss2id323

Solomon, R. (2016). He whare köiwi: Integrating traditional and contemporary funeral practices for the modern Màori [Unpublished master's exegesis]. Te Wānanga o Aotearoa. State of Ohio Department of Health Environmental Protection Agency (1993). Blood in the sewer system: Does it pose a health risk? Retrieved from https://www.epa.ohio.gov/portals/34/document/guida nce/gd_105.pdf 
Statistics New Zealand (2019). Losing our religion. Retrieved from https://www.stats.govt.nz/news/losing-our$\underline{\text { religion }}$

Towndrow, S., Truscott, G. \& Butler, R. (2010, August 4). Improving the effluent discharge from oxidation ponds in New Zealand with membrane polishing [Conference session]. Water New Zealand Annual Conference. https://www.waternz.org.nz/Article?Action=View\&Articl e_id $=816$

Wangu, M. B. (2001). Hinduism. Facts on File.

Williams, H. W. (1971). Dictionary of the Maori language ( $7^{\text {th }}$ ed.). GP Publications. 